\title{
Influence of carcass temperature, glycogenolysis and glycolysis 45 min postmortem on the development of PSE pork
}

\author{
MARKKU HONKAVAARA \\ Finnish Meat Research Centre, Box 56, \\ SF-13101 Hämeenlinna, Finland
}

\begin{abstract}
This study investigated the effect of slaughter stress, scalding and process time from stunning to chilling on carcass temperature, muscle glycogen and lactate content, and the development of PSE meat $\left(\mathrm{pH}_{1} \leq 5.8\right)$.

Blood creatine kinase $(\mathrm{CK})$ activity was positively $(\mathrm{P}<0.001)$ related to carcass temperature at slaughter. During scalding, carcass temperature raised by $1.2 \pm 1.4^{\circ} \mathrm{C}, 13 \%$ of muscle glycogen was broken down and lactate level elevated by $5 \%$. Furthermore carcass temperature fell by $0.7 \pm 0.8^{\circ} \mathrm{C}, 5 \%$ of muscle glycogen was consumed and lactate content increased by $35 \%$ between scalding and chilling.

The time elapsed from stunning to splitting and further to chilling had a minor effect on carcass temperature, muscle glycogen or lactate content. Whereas, lactate production was positively correlated with the increase in carcass temperature both during scalding $(\mathrm{P}<0.01)$ and between stunning and chilling $(\mathrm{P}<0.01)$, and with muscle glycogen breakdown $(\mathrm{P}<0.001)$. Consequently, the enhanced glycogenolysis during scalding, the accelerated glycolysis between scalding and chilling, and the elevated carcass temperature 45 min postmortem (p.m.) resulted in the development of PSE meat.
\end{abstract}

Index words: slaughter, creatine kinase, postmortem glycogenolysis, glycolysis, PSE meat

\section{Introduction}

The efforts to imrove pork quality should include the proper handling and management of pigs all along the line from farm to chilling. At the abattoir, the treatments just before slaughtering are easier to control than the p.m. biochemical reactions triggered by stressful handling.

$$
\text { Wismer-Pedersen and Briskey (1961a) }
$$

presented four types of p.m. pH falls: a slow gradual, a gradual, a relatively rapid and a sharp, significant decrease. PSE meat resulted when $\mathrm{pH}_{1}$ (45 min p.m.) was decreased to about 5.4 while tissue temperature remained above $25^{\circ} \mathrm{C}$. However, the accelerated chilling rate had no significant effect on final lactic acid content but it did reduce the rate of 
lactate formation (WISMER-PEDERSEN and BRISKEY, 1961b).

The heat production and loss from muscles were brought to equilibrium $30 \mathrm{~min}$ p.m. (Bierning-Sørensen, 1976). Moreover, the rigor and temperature measurements $45 \mathrm{~min}$ p.m. gave information about the intensity of treatment before and during slaughtering (Sybesma and van Logtestiun, 1966). Finally, the rapid $\mathrm{pH}$ fall combined with a high carcass temperature developed PSE meat (WoLTERSDORF and TROEGER, 1987).

Earlier papers (HonKAVAarA, 1988, 1989a and 1989b) considered the effect of porcine stress on blood composition and early p.m. meat quality in pigs of different halothane genotypes; the influence of selection phase, fasting and transport on porcine stress and on the development of PSE; and the influence of lairage on blood composition of pig and on the occurrence of PSE.

The purpose of this study was to evaluate the effect of blood CK activity and slaughter line on carcass temperature, muscle lactate and glycogen content, and the development of PSE.

\section{Material and methods}

\section{Test animals}

38 Finnish Landrace (L) pigs, 8 Finnish Yorkshire (Y) pigs and $56 \mathrm{LxY}$ crosses were slaughtered at three abattoirs. The Central Association of Artificial Insemination Societies determined the halothane genotype of 52 animals, and the results were combined by the Finnish Animal Breeding Association to get the probability for the genotype, the rest were of unknown genotype. The collection and treatment of animals are described earlier (HonkavaAra, 1989a, 1989b).

\section{Measurements at the abattoir}

The temperature and relative humidity were measured with a portable hygrometer $(\mathrm{Hu}-$ micap HMI 31, Vaisala, Finland) in the lairage and on the slaughter line at splitting and before carcass chilling. Moreover, it was measured scalding temperature and time, the time elapsed from stunning to splitting, and from splitting to chilling.

\section{Evaluation of meat quality}

Methods used for the evaluation of meat quality are described earlier (HonkavaARA, 1988). Furthermore, the increase in carcass temperature during scalding and that from stunning to chilling were calculated by subtracting the temperature of $0 \mathrm{~min}$ p.m. from that of $10 \mathrm{~min}$ p.m. and from that of $45 \mathrm{~min}$ p.m., respectively. In addition, the rate of muscle glycogen breakdown and lactate formation were calculated from the samples of M. longissimus dorsi (LD) by the formulas:

micromoles ( $\mu \mathrm{mol})$ of glycogen $(\mathrm{MG})$ broken down per $100 \mathrm{~g}$ of wet tissue in one minute $=$

MG 0 min p.m. $(\mu \mathrm{mol} / 100 \mathrm{~g})-\mathrm{MG} 45 \mathrm{~min}$ p.m. $(\mu \mathrm{mol} / 100)$ time elapsed from exsanguination to chilling $(\mathrm{min})$.

$\mu$ mol of lactate (ML) formed per $100 \mathrm{~g}$ of wet tissue in one minute $=$

ML 45 min p.m. ( $\mu \mathrm{mol} / 100 \mathrm{~g})-$ ML 0 min p.m. $(\mu \mathrm{mol} / 100 \mathrm{~g})$ time elapsed from exsanguination to chilling $(\mathrm{min})$

\section{Variables}

The following 34 variables were used in statistical analyses: loading time of day, transport temperature and duration (TD), lairage time, temperature of lairage (TL), humidity of lairage, stunning time of day (ST), fasting duration (FD), scalding temperature (STE) and time (STI), temperature on line at splitting and that before chilling (TEC), humidity on line at splitting and that before chilling, time elapsed from stunning to splitting (TS) and that elapsed from splitting to chilling (TC); blood creatine kinase (CK) activity on farm, during unloading and at exsanguination (CKE); serum glucose (SG), glycerol, lactate and $\mathrm{pH}$; carcass temperature $0\left(\mathrm{CT}_{0}\right), 10$ $\left(\mathrm{CT}_{10}\right)$ and $45 \mathrm{~min}$ p.m. $\left(\mathrm{CT}_{45}\right)$; muscle glyco- 
gen $0\left(\mathrm{MG}_{0}\right), 10\left(\mathrm{MG}_{10}\right)$ and $45 \mathrm{~min}$ p.m. $\left(\mathrm{MG}_{45}\right)$; muscle lactate $0\left(\mathrm{ML}_{0}\right), 10\left(\mathrm{ML}_{10}\right)$ and 45 min p.m. $\left(\mathrm{ML}_{45}\right)$; muscle $\mathrm{pH} 45 \mathrm{~min}$ p.m. $\left(\mathrm{pH}_{1}\right)$ and carcass hot weight $(\mathrm{CW})$. The CK values were $\log _{10}$ transformed.

\section{Statistical analyses}

Conventional statistical methods were used to calculate means, standard deviations and standard error of the means (SEM). The relations between the measured variables and meat quality traits were analysed by simple regression. The difference among the means were evaluated by analysis of variance. Moreover, stepwise regression analyses were used to examine the relative predictive value of the measured variables for carcass temperature, muscle glycogen, lactate and $\mathrm{pH}$ value $45 \mathrm{~min}$ p.m. (statistical program PATO for microcomputers, Mikrovuo, Finland).

The regression model (1) included the dependent variable $Y_{i}(i=1-8)$ and the 33 independent variables $\mathrm{X}_{\mathrm{j}}(\mathrm{j}=1-33, \mathrm{j} \neq 1)$ and the standardized regression coefficients $B_{j}$ $(j=1-33, j \neq i)$.

$\mathrm{Y}_{\mathrm{i}}=\mathrm{B}_{1} \mathrm{X}_{1}+\mathrm{B}_{2} \mathrm{X}_{2}+\mathrm{B}_{3} \mathrm{X}_{3}+\ldots+\mathrm{B}_{33} \mathrm{X}_{33}$

Prediction equations (2) were developed using stepwise regression analysis (HonKavaA. RA, 1989a).

$$
\begin{aligned}
Y_{i}= & B_{0}+B_{1} X_{1}+B_{2} X_{2}+\ldots+B_{n} X_{n} \\
& (i=1-8, n=3-6)
\end{aligned}
$$

\section{Results}

\section{Prediction of the development of PSE meat}

Table 1 shows the combined effects of studied variables on muscle $\mathrm{pH}_{1}$ value and on the changes in carcass temperature, muscle glycogen and lactate content $45 \mathrm{~min}$ p.m. Thus, the coefficient of determination $\left(\mathrm{R}^{2}\right.$ 100) of the prediction equations were for the rate of lactate formation and glycogen breakdown, increase in carcass temperature from

Table 1. The best stepwise regression models ${ }^{a}$ for predicting biochemical changes in the M. longissimus dorsi

\begin{tabular}{|c|c|c|}
\hline Prediction equations ${ }^{b}$ & $\mathrm{R}^{2} 100$ & $\mathrm{Df}^{\mathrm{u}}$ \\
\hline $\begin{array}{l}\text { Carcass temperature } 45 \mathrm{~min} \text { p.m. }= \\
\quad 6.152+0.247 \mathrm{TD}+0.209 \mathrm{FD}+0.601 \mathrm{CT}_{10}+0.217 \mathrm{ML}_{45}+0.227 \mathrm{CW}\end{array}$ & 74.2 & $5 / 56$ \\
\hline $\begin{array}{l}\text { Increase in carcass temperature during scalding }= \\
\quad 31.892-0.603 \mathrm{CT}_{0}+0.206 \mathrm{SG}+0.218 \mathrm{SGL}-0.213 \mathrm{MG}_{0}\end{array}$ & 60.4 & $4 / 50$ \\
\hline $\begin{array}{l}\text { Increase in carcass temperature from stunning to chilling }=11.523 \\
\quad+0.247 \mathrm{FD}+0.37 \mathrm{TEC}-0.965 \mathrm{CT}_{0}+0.569 \mathrm{CT}_{10}+0.241 \mathrm{ML}_{45}+0.196 \mathrm{CW}\end{array}$ & 84.9 & $6 / 48$ \\
\hline $\begin{array}{l}\text { Muscle glycogen } 45 \min \text { p.m. }= \\
\quad 515.25-0.167 \mathrm{FD}+0.504 \mathrm{MG}_{10}+0.178 \mathrm{ML}_{0}-0.471 \mathrm{ML}_{45}\end{array}$ & 63.9 & $4 / 94$ \\
\hline $\begin{array}{l}\text { Muscle lactate } 45 \min \text { p.m. }= \\
\quad 9.054-0.237 \mathrm{TD}+0.349 \mathrm{ST}-0.392 \mathrm{MG}_{45}+0.377 \mathrm{ML}_{0}-0.31 \mathrm{pH}\end{array}$ & 70.6 & $5 / 59$ \\
\hline $\begin{array}{l}\text { Rate of glycogen breakdown from stunning to chilling }= \\
\qquad-6.393+0.133 \mathrm{STI}+0.948 \mathrm{MG}_{0}-1.021 \mathrm{MG}_{45}\end{array}$ & 96.1 & $3 / 96$ \\
\hline $\begin{array}{l}\text { Rate of lactate formation from stunning to chilling }= \\
4.493-0.112 \mathrm{TS}-0.198 \mathrm{TC}-0.715 \mathrm{ML}_{0}+1.063 \mathrm{ML}_{45}\end{array}$ & 96.9 & $4 / 86$ \\
\hline $\begin{array}{l}\mathrm{pH}_{1}= \\
\quad 11.148+3.14 \mathrm{TL}-0.325 \mathrm{CT}_{10}-0.217 \mathrm{ML}_{10}-0.382 \mathrm{ML}_{45}\end{array}$ & 60.2 & $4 / 50$ \\
\hline
\end{tabular}
45 min postmortem.

a Regression models have significant F-values $(\mathrm{P}<0.002)$.

Abbreviations given in text.

Coefficient of determination $\times 100$

d Degrees of freedom. 
stunning to chilling and during scalding, and muscle $\mathrm{pH}_{1}$ 96.9, 96.1, 84.9, 60.4 and $60.2 \%$, respectively. In addition, the $\mathrm{R}^{2} 100$ values of prediction equations for carcass temperature, muscle lactate and glycogen $45 \mathrm{~min}$ p.m. were respectively $74.2,70.6$ and $63.9 \%$. The combined effects of the independent variables of the prediction equations are discussed below.

\section{Carcass temperature during scalding}

The average increase in carcass temperature during scalding was $1.2 \pm 1.4^{\circ} \mathrm{C}$. Carcass temperature $0 \mathrm{~min}$ p.m. was highly significantly positively correlated with $\log \mathrm{CK}$ at exsanguination $(r=0.47, P<0.001)$. Moreover, this CK activity contributed $12.9 \%$ of the variation in carcass temperature 0 min p.m. (HoNKAVAARA, 1989a). Figure 1 shows the difference in carcass temperature before and after scalding between the pigs with a low and elevated CK activity. Thus carcass temperatures of 38.5 and $39.6^{\circ} \mathrm{C}$ at slaughter, $\mathrm{X}$, led to the respective temperature increases of 1.3 and $0.4^{\circ} \mathrm{C}$ during scalding, $\mathrm{Y}(\mathrm{Y}=35.985-$ $\left.0.902 \mathrm{X}, \mathrm{R}^{2} 100=45 \%, \mathrm{P}<0.001\right)$. On the other hand, the higher the blood CK activity at exsanguination, $\mathrm{X}$ the smaller was the increase in carcass temperature during scalding, $\mathrm{Y}\left(\mathrm{Y}=3.757-0.728 \log \mathrm{X}, \mathrm{R}^{2} 100=8 \%\right.$, $\mathrm{P}<0.05)$.

The most contributing components of the increase in carcass temperature during scald-

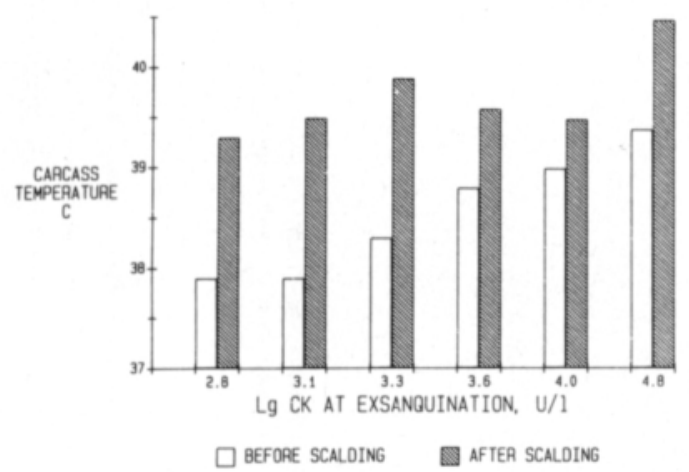

Fig. 1. Effect of CK activity (logarithmic transformation) at exsanguination on carcass temperature. ing were carcass temperature 0 min p.m., serum glucose and glycerol, and muscle glycogen 0 min p.m. (partial $\mathrm{R}^{2} 100=45.3,5.9$, 4.9 and $4.3 \%$, respectively, Table 1 ). In the present study, neither stunning order nor carcass hot weight had no significant influence on the increase in carcass temperature during scalding.

The lactate content of the LD muscle of the carcasses with the highest CK values were 45.6 $\mu \mathrm{mol} / \mathrm{g}$ before scalding and $62.2 \mu \mathrm{mol} / \mathrm{g}$ after scalding. The former value was in the mean range of $45.5 \pm 12.2 \mu \mathrm{mol} / \mathrm{g}$, whereas the latter was significantly $(\mathrm{P}<0.05)$ higher than the respective average value of $47.8 \mu \mathrm{mol} / \mathrm{g}$ in this study. So it was suggested that the great occurrence of reactors $(20 \%)$ led to a high heat generation due to accelerated glycolysis during scalding in carcasses with the highest CK values (Fig. 1). Furthermore, the effect of halothane genotype on carcass temperature is discussed more accurately earlier (HonKAvAARA, 1988).

\section{Carcass temperature from stunning to chilling}

The average carcass temperature 0 and 45 min p.m. was $38.6 \pm 1.0$ and $39.0 \pm 1.1^{\circ} \mathrm{C}$, respectively. Moreover, the mean increase in carcass temperature during scalding and that from stunning to chilling was respectively $1.2 \pm 1.4$ and $0.5 \pm 1.3^{\circ} \mathrm{C}$. Consequently, carcass temperature fell by $0.7 \pm 0.8^{\circ} \mathrm{C}$ between scalding and chilling.

In order to present the influence of carcass temperature on meat quality, the collected data were classified into three groups of nearly the same number of pigs according to the carcass temperature rise between stunning and chilling. Consequently, Table 2 shows the variation in those variables that differed significantly between the groups.

On the slaughter line, the increase in carcass temperature was negatively correlated with the temperature $(\mathrm{r}=-0.49, \mathrm{P}<0.001)$ and humidity $(\mathrm{r}=-0.49, \mathrm{P}<0.001)$ at splitting, temperature $(\mathrm{r}=-0.47, \mathrm{P}<0.001)$ and 
Table 2. Effect of carcass temperature on studied variables.

\begin{tabular}{|c|c|c|c|c|}
\hline \multirow[t]{2}{*}{ Variable } & \multicolumn{3}{|c|}{$\begin{array}{l}\text { Change in carcass temperature } \\
\text { from stunning to chilling, }{ }^{\circ} \mathrm{C}\end{array}$} & \multirow[t]{2}{*}{ SEM } \\
\hline & $-0.8 \pm 0.7$ & $0.3 \pm 0.2$ & $2.0 \pm 0.7$ & \\
\hline Temperature on line at splitting,${ }^{\circ} \mathrm{C}$ & $22.3^{a}$ & $21.5^{a}$ & $19.7^{\mathrm{b}}$ & 0.33 \\
\hline Humidity & $62.1^{\mathrm{a}}$ & $60.0^{3}$ & $45.5^{b}$ & 1.56 \\
\hline $\begin{array}{l}\text { Temperature on line before chilling, }{ }^{\circ} \mathrm{C} \\
\text { Humidity }\end{array}$ & $\begin{array}{l}20.8^{a} \\
55.3\end{array}$ & $\begin{array}{l}19.9 \\
58.2^{a}\end{array}$ & $\begin{array}{l}17.7^{b} \\
44.5^{b}\end{array}$ & $\begin{array}{l}0.34 \\
1.65\end{array}$ \\
\hline Time elapsed from stunning to splitting, min & $34.4^{\mathrm{a}}$ & $31.9^{\mathrm{b}}$ & 32.4 & 0.46 \\
\hline Time elapsed from splitting to chilling, min & $23.4^{\mathrm{a}}$ & $23.8^{a}$ & $27.3^{\mathrm{b}}$ & 0.54 \\
\hline Carcass temperature 0 min p.m., ${ }^{\circ} \mathrm{C}$ & $39.0^{\mathrm{a}}$ & $38.8^{\mathrm{a}}$ & $37.9^{b}$ & 0.13 \\
\hline Increase in carcass temperature during scalding, ${ }^{\circ} \mathrm{C}$ & $0.2^{\mathrm{a}}$ & $0.8^{\mathrm{b}}$ & $2.7^{c}$ & 0.20 \\
\hline $\begin{array}{l}\text { Rate of glycogen breakdown from stunning to chilling, } \\
\mu \mathrm{mol} /(100 \mathrm{~g} \times 1 \mathrm{~min})\end{array}$ & $-2.5^{a}$ & 1.2 & $11.1^{\mathrm{b}}$ & 0.44 \\
\hline $\begin{array}{l}\text { Rate of lactate formation from stunning to chilling, } \\
\mu \mathrm{mol} /(100 \mathrm{~g} \times \mathrm{min})\end{array}$ & $17.8^{a}$ & $23.3^{a}$ & $51.1^{\mathrm{b}}$ & 0.34 \\
\hline Carcass hot weight, $\mathrm{kg}$ & 76.9 & 77.8 & 76.3 & 0.79 \\
\hline Prime grading class, $\mathrm{E}+, \%$ & 30.0 & 50.0 & 27.8 & - \\
\hline $\begin{array}{r}\mathrm{pH}_{1} \leq 5,8, \% \\
5.8<\mathrm{pH}_{1} \leq 6.4, \\
6.4<\mathrm{pH}_{1}, ",\end{array}$ & $\begin{array}{c}0 \\
45.0 \\
55.0\end{array}$ & $\begin{array}{l}11.1 \\
50.0 \\
38.9\end{array}$ & $\begin{array}{r}38.9 \\
55.5 \\
5.6\end{array}$ & $\begin{array}{l}- \\
- \\
-\end{array}$ \\
\hline Reactors $\quad, \%$ & 0 & 0 & 27.8 & - \\
\hline Number of pigs & 20 & 18 & 18 & - \\
\hline
\end{tabular}

a. h.c Means within a row with different supersripts are significantly different $(\mathrm{P}<0.05)$.

humidity $(\mathrm{r}=-0.32, \mathrm{P}<0.05)$ before chilling, whereas it had a positive correlation with the time elapsed from splitting to chilling $(r=0.47, P<0.001)$. Furthermore, between stunning and chilling, the carcass temperature rise was negatively related to the carcass temperature 0 min p.m. $(r=-0.53, P<0.001)$, muscle glycogen content 45 min p.m. $(r=$ $-0.30, \mathrm{P}<0.05)$ and $\mathrm{pH}_{1}$ value $(\mathrm{r}=-0.58$, $\mathrm{P}<0.001$ ), while it had a positive relationship with the increase in carcass temperature during scalding $(\mathrm{r}=0.82, \mathrm{P}<0.001)$, carcass temperature $10(\mathrm{r}=0.58, \mathrm{P}<0.001)$ and $45 \mathrm{~min}$ p.m. $(r=0.67, P<0.001)$ and muscle lactate content 45 min p.m. $(r=0.42, P<0.01)$.

The most contributing variables of carcass temperature 45 min p.m. were carcass temperature after scalding (partial $\mathrm{R}^{2} 100=42.7 \%$ ), fast $(14.5 \%)$ and transport duration $(7.5 \%)$, whereas carcass hot weight and muscle lactate content 45 min p.m. made relatively minor contributions (4.9 and $4.6 \%$, respectively,
Table 1). In addition, the carcass temperature rise from stunning to chilling was determined mainly by carcass temperature after scalding $(34.8 \%)$, temperature on line before chilling $(20.1 \%)$, carcass temperature at slaughter $(11.2 \%)$ and fast duration $(10.4 \%)$, and minimally by the muscle lactate content 45 min p.m. $(4.8 \%)$ and carcass hot weight (3.6\%, Table 1).

The present results suggested that the degree of metabolic stimulation of muscles at exsanguination determined the temperature of carcass 10 and $45 \mathrm{~min}$ p.m. Actually the carcasses with the most prominent temperature rise between stunning and chilling had the highest $(\mathrm{P}<0.001)$ increase in temperature during scalding. In contrast, the time elapsed from stunning to splitting and from splitting to chilling had a minor effect on carcass temperature. On the other hand, the temperature rise $45 \mathrm{~min}$ p.m. was below the average value of $0.5^{\circ} \mathrm{C}$ in carcasses with the greatest amount 
of prime grading class. Finally, the group that included all reactors had the most prominent increase in temperature $45 \mathrm{~min}$ p.m. and the highest PSE frequency (Table 2).

\section{Rate of muscle glycogen breakdown}

The average muscle glycogen content 0,10 and $45 \mathrm{~min}$ p.m. was $28.4 \pm 12.3,24.7 \pm 12.3$ and $23.5 \pm 13.6 \mu \mathrm{mol} / \mathrm{g}$, respectively. This showed the most prominent decrease in glycogen during scalding and a minor decline afterwards. Thus $17.4 \%$ of the glycogen was broken down 45 min p.m. which corresponded to a breakdown rate of $9.9 \pm 23.5$ $\mu \mathrm{mol} /(100 \mathrm{~g} \times \mathrm{min})$.

Scalding times, $\mathrm{X}$ of 6 and $6.5 \mathrm{~min}$ resulted in the rates of glycogen breakdown, $\mathrm{Y}$ of 1.1 and $4.1 \mu \mathrm{mol} /(100 \mathrm{~g} \times \mathrm{min})$, respectively $\left(\mathrm{Y}=-106.85+17.99 \mathrm{X}, \mathrm{R}^{2} 100=18 \%, \mathrm{P}<\right.$ $0.001)$. Whereas the decline in glycogen content was not significantly related to scalding temperature. Furthermore, on the line, glycogen breakdown was negatively correlated with temperature at splitting $(\mathrm{r}=-0.29, \mathrm{P}<0.01)$, humidity before chilling $(\mathrm{r}=-0.25, \mathrm{P}<0.05)$ and time elapsed from stunning to splitting $(\mathrm{r}=-0.34, \mathrm{P}<0.01)$.

The most contributing components of muscle glycogen content $45 \mathrm{~min}$ p.m. were muscle glycogen level after scalding $(44.1 \%)$ and muscle lactate content 45 min p.m. (15.3\%), while muscle lactate at slaughter $(2.5 \%)$ and fast duration $(2.0 \%)$ made relatively minor contributions (Table 1). In addition, the rate of glycogen breakdown from stunning to chilling was determined best by muscle glycogen level $45(69.0 \%)$ and $0 \mathrm{~min}$ p.m. (12.0\%), and scalding time $(15.1 \%)$.

The present results suggested that it was difficult to predict meat quality on the basis of muscle glycogen content which, however, will have an important influence on the development of PSE pork through the glycolytic pathway.

\section{Rate of muscle lactate formation}

The average muscle lactate content 0,10 and $45 \mathrm{~min}$ p.m. was $45.6 \pm 12.2,47.8 \pm 14.4$ and $64.4 \pm 17.8 \mu \mathrm{mol} / \mathrm{g}$, respectively. Thus production of lactate was low during scalding, whereas it was greatest afterwards. Consequently, lactate level increased by $41.5 \% 45$ min p.m. which corresponded to a formation rate of $35.6 \pm 30.0 \mu \mathrm{mol} /(100 \mathrm{~g} \times \mathrm{min})$.

A 0.6 and $1.2^{\circ} \mathrm{C}$ increase in carcass temperature during scalding, $\mathrm{X}$ enhanced lactate production $45 \mathrm{~min}$ p.m., $\mathrm{Y}$ by 26.0 and 30.5 $\mu \mathrm{mol} /(100 \mathrm{~g} \times \mathrm{min})$, respectively $(\mathrm{Y}=21.533$ $\left.+7.511 X, \mathrm{R}^{2} 100=13 \%, \mathrm{P}<0.01\right)$. Moreover, carcass temperature elevation from stunning to chilling, $\mathrm{X}$ of 0 and $0.5^{\circ} \mathrm{C}$ resulted in lactate accumulation, $\mathrm{Y}$ by 26.7 and 30.9 $\mu \mathrm{mol} /(100 \mathrm{~g} \times \mathrm{min})$, respectively $(\mathrm{Y}=26.744$ $+8.378 \mathrm{X}, \mathrm{R}^{2} 100=15 \%,(\mathrm{P}<0.01)$. As a result, muscle lactate content $45 \mathrm{~min}$ p.m. was highly correlated with the rate of lactate formation $(r=0.99, \mathrm{P}<0.001)$.

Muscle lactate content $45 \mathrm{~min}$ p.m. was determined mainly by muscle glycogen $45 \mathrm{~min}$ p.m. $(36.5 \%)$, lactate 0 min p.m. $(13.5 \%)$ and stunning time $(11.7 \%)$, and minimally by muscle $\mathrm{pH}_{1}$ value $(7.0 \%)$ and transport duration $(1.9 \%)$. In fact, muscle lactate content $45 \mathrm{~min}$ p.m. was the single best predictor $(83.5 \%)$ of lactate production, whereas the time elapsed from stunning to splitting $(6.3 \%)$, muscle lactate level at slaughter $(5.2 \%)$ and time elapsed from splitting to chilling $(1.9 \%)$ made relatively minor contributions (Table 1). Finally, the most useful predictors of muscle $\mathrm{pH}_{1}$ were carcass temperature $(34.6 \%)$ and muscle lactate $(12.1 \%)$ after scalding, muscle lactate $45 \mathrm{~min}$ p.m. $(8.3 \%)$ and lairage temperature $(5.2 \%)$. In summary, it was concluded that muscle lactate content provided a useful predictor of meat quality, especially that of PSE pork.

\section{Discussion}

In general, blood CK activity and carcass hot weight correlated negatively with carcass 
temperature rise during scalding. Moreover without reactors, carcass temperature fell between stunning and chilling. Whereas in reactors, carcass temperature raised due to accelerated glycolysis during scalding and $45 \mathrm{~min}$ p.m. which resulted in the development of PSE. This agreed with SCHNEIDER et al. (1980) who found that reactors had the highest $\mathrm{CK}$ activity and the lowest $\mathrm{pH}_{1}$ value. In addition, Sybesma and van LogTestiun (1966) found that a high carcass temperature was related to a rapid $\mathrm{pH}$ fall and the onset of rigor.

The rate of glycogenolysis was fastest during scalding after that it reduced up to the chilling. Carcasses with the most prominent rate of glycogen breakdown had the highest muscle glycogen content $0 \mathrm{~min}$ p.m. and the greatest PSE frequency. This was consistent with Wismer-Pedersen and Briskey (1961a) that a muscle with a sharp $\mathrm{pH}$ fall of 5.1 at $1.5 \mathrm{~h}$ contained more glycogen at slaughter than those with a slower $\mathrm{pH}$ fall.

Lactate production was low during scalding but it enhanced from scalding to chilling. Thus it was suggested that, during scalding, a major part of glycogen was broken down

\section{References}

Biering-Sorensen, U. af 1976. PSE (Pale Soft Exudative) eller såkaldt "muskeldegeneration" hos svin. I. Dansk Vet. Tidsskr. 59: 809-822.

Honkavaara, M. 1988. Influence of porcine stress on blood composition and early postmortem meat quality in pigs of different halothane genotypes. Meat Sci. 24: $21-29$.

- 1989a. Influence of selection phase, fasting and transport on porcine stress and on the development of PSE pork. J. Agric. Sci. Finl. 61 (3): 415-423.

- 1989b. Influence of lairage on blood composition of pig and on the development of PSE pork. J. Agric. Sci. Finl. 61 (3): 425-432.

Lawrie, R.A. 1960. Postmortem glycolysis in normal and exudative longissimus dorsi muscles of pigs in relation to so-called white muscle disease. J. Comp. Pathol. Ther. 70: 273-295.

Schneider, A., Schworer, D. \& Blum, J. 1980. Beziehung des Halothan-Genotyps zu den Produktions- to glucose, whereas a minor part of glucose was degraded to yield lactate. After scalding, a major part of glucose was consumed in glycolysis to produce lactic acid. This production was accelerated by elevated carcass temperature. On the other hand, the carcasses with the fastest rate of lactate formation included a great amount of reactors, had the smallest proportion of prime grading class and the highest occurrence of PSE. A similar result was obtained by LAWrie (1960) that a fast rate of glycolysis was associated with a great degree of exudation.

In summary, the results suggested that to avoid the development of PSE meat the rate of glycogenolysis and glycolysis should be reduced so that the carcass temperature will raise as low as possible during scalding and there will be a total fall in carcass temperature 45 min p.m.

Acknowledgements. The author wishes to thank abattoir personnel of Itikka Lihabotnia and LSO Food for co-operation. Thanks are extended to the Central Association of Artificial Insemination Societies and to the Finnish Animal Breeding Association for genotype determination. Thanks are also given to Mrs. Kirsti Rantanen for laboratory analysis. This investigation was supported by the Finnish Academy.

und Reproduktionsmerkmalen der Schweizerischen Landrasse. 31st Ann. Mtg. EAAP, Munich, paper GP $3.9,6 \mathrm{pp}$.

Sybesma, W. \& Logtestiun, J.G. Van. 1966. Preslaughter temperature and its effect on postmortem metabolism in the pig. Proc. 12th Eur. Meet. of Meat Res. Workers, Sandefjord, paper E 13, 11 pp.

Wismer-Pedersen, J. \& Briskey, E.J. 1961a. Rate of anaerobic glycolysis versus structure in pork muscle. Nature 189: 318-320.

Wismer-Pedersen, J. \& Briskey, E.J. 1961b. Relationship on postmortem acidity and temperature. Food Technol. 15: 232-236.

Woltersdorf, W. \& Troeger, K. 1987. Schlachttechnik zur Verringerung des PSE-Anteils beim Schwein. Fleischwirtsch. 67: 724-730.

Ms received July 4, 1988 


\section{SELOSTUS}

\section{Ruholämpötilan, glykogenolyysin ja glykolyysin vaikutus PSE-lihan muodostumiseen 45 min postmortem}

\author{
Markku Honkavaara \\ Lihateollisuuden Tutkimuskeskus, \\ PL 56, 13101 Hämeenlinna
}

Tutkimuksessa selvitettiin teurastusstressin, kalttauksen ja tainnutuksesta pikajäähdytykseen kuluneen ajan vaikutus ruholämpötilaan, lihaksen glykogeeni- ja maitohappopitoisuuteen sekä PSE-lihan $\left(\mathrm{pH}_{1} \leq 5.8\right)$ muodostumiseen.

Mită suurempi oli veren kreatiinikinaasi- (CK-) aktiivisuus sită korkeampi ruholämpötila $(\mathrm{P}<0.001)$. Kalttauksen aikana ruholämpötila kohosi $1.2 \pm 1.4^{\circ} \mathrm{C}$, lihaksen glykogeenistä hajosi $13 \%$ ja maitohappopitoisuus kasvoi $5 \%$. Ruhon kulkiessa kalttauksesta pikajäăhdytykseen sen lämpötila aleni $0.7 \pm 0.8^{\circ} \mathrm{C}$, lihaksen glykogeenipitoisuus văheni $5 \%$ ja maitohappoa muodostui li-

\section{săă $35 \%$.}

Ruhon kulkuaika pistosta halkaisuun ja siitä pikajäăhdytykseen ei vaikuttanut merkittävästi sen lämpötilaan, lihaksen glykogeeni- tai maitohappopitoisuuteen. Sen sijaan maitohapon muodostumista lisäsivăt kohonnut ruholämpötila kalttauksessa $(\mathrm{P}<0.01)$ ja pistosta pikajāähdytykseen $(\mathrm{P}<0.01)$ sekä kiihtynyt glykogeenin hajoaminen $(\mathrm{P}<0.001)$. PSE-lihan muodostumisen aiheuttivat glykogenolyysin voimistuminen kalttauksessa, glykolyysin kiihtyminen kalttauksesta pikajäähdytykseen ja korkea ruholämpötila $45 \mathrm{~min}$ postmortem. 